\title{
Increased Expression of Heat Shock Protein 65 Coincides with a Population of Infiltrating T Lymphocytes in Atherosclerotic Lesions of Rabbits Specifically Responding to Heat Shock Protein 65
}

\author{
Qingbo Xu, * Roman Kleindienst, ${ }^{*}$ Werner Waitz, ${ }^{5}$ Hermann Dietrich, ${ }^{*}$ and Georg Wick * \\ *Institute for Biomedical Aging Research, Austrian Academy of Sciences; ${ }^{\ddagger}$ Institute for General and Experimental Pathology; and \\ ${ }^{\S}$ Institute for Physiology, University of Innsbruck, Medical School, A-6020 Innsbruck, Austria
}

\begin{abstract}
We have shown previously that atherosclerotic lesions can be induced in normocholesterolemic rabbits by immunization with mycobacterial heat shock protein 65 (hsp65), which has a high degree of sequence homology with mammalian hsp60. To investigate a possible relationship between hsp60 expression and the antigenic specificities of infiltrating $T$ cells in the lesion, 38 New Zealand White rabbits were treated either by immunization with recombinant mycobacterial hsp65 or by administration of a $0.2 \%$ cholesterol diet. Atherosclerotic lesions were observed after $16 \mathrm{wk}$, particularly in the aortic arch and arterial bifurcations of rabbits immunized with hsp65 or fed with a cholesterol-rich diet. Hsp65 staining of aortas showed a heterogeneous distribution, and significantly increased staining intensity in atherosclerotic lesions compared to aortic media or adventitia. This abundantly expressed hsp65 was observed in atherosclerotic lesions induced by hsp65 immunization as well as those induced by cholesterol-rich diet alone. Interestingly, a population of the $T$ lymphocytes isolated from all forms of atherosclerotic lesions specifically responded to hsp65 in vitro. IL-2-expanded $T$ cell lines derived from atherosclerotic lesions showed a significantly higher hsp65 reactivity than those developed from peripheral blood of the same donor. Furthermore, levels of circulating antibodies and numbers of spleen cells specifically reacting against hsp65 were elevated in all experimental animals. Flow cytometric analysis of spleen cells showed elevated immune response-associated antigen expression in treated animals. In conclusion, increased hsp65 expression in intimal cells and the presence of hsp65-specific $T$ cells in blood and in atherosclerotic lesions may be important in initiating the development of atherosclerosis and perpetuating the lesions. (J. Clin. Invest. 1993.91:2693-2702.) Key words: atherosclerosis • heat shock proteins • T lymphocytes • autoimmunity • cholesterol
\end{abstract}

Address correspondence to Qingbo Xu, M.D., Institute for Biomedical Aging Research, Austrian Academy of Sciences, Rennweg 10, A-6020 Innsbruck, Austria.

Received for publication 25 September 1992 and in revised form 29 December 1992.

1. Abbreviations used in this paper: Con A, concanavalin A; FCA, Freund's complete adjuvant; FIA, Freund's incomplete adjuvant; hsp, heat shock protein; Ia, immune response-associated antigens; PPD, purified protein derivative of mycobacteria; SI, stimulation index.

J. Clin. Invest.

(c) The American Society for Clinical Investigation, Inc. $0021-9738 / 93 / 06 / 2693 / 10 \$ 2.00$

Volume 91, June 1993, 2693-2702

\section{Introduction}

Heat shock proteins (hsp) ${ }^{1}$ are proteins with a high degree of sequence homology between different species, from bacteria to man $(1,2)$. Hsp expression can be induced or augmented by heat treatment (3), exposure to oxygen radicals or cytokines $(4,5)$, ischemia $(6,7)$, hemodynamic overload $(8)$, surgical stress (9), and viral infection (10). Hsp may play an important role in normal and pathological immune reactions, through involvement in antigen processing and immunoglobulin folding, and could participate in the pathogenesis of autoimmune processes via antigenic cross-reactivity $(1,2)$.

Epidemiological studies in our laboratory have shown that serum antibodies against hsp65 were significantly $(P<0.01)$ increased in subjects with carotid atherosclerosis compared to those without the lesions, and these increased antibody levels were independent of age and sex. Our data provide the first evidence of a strong correlation of hsp65 antibodies with carotid atherosclerosis in humans (11).

With regard to animal experiments, we have immunized rabbits one or more times with various antigens, with or without adjuvants (12). The antigens and adjuvants, respectively, included human and rabbit atherosclerotic lesion proteins, ovalbumin, recombinant mycobacterial hsp65, Freund's complete and incomplete adjuvants (FCA, FIA), and two hsp-free adjuvants, Ribi and lipopeptide. $16 \mathrm{wk}$ after the first immunization, arteriosclerotic lesions in the intima of the aortic arch were found to develop only in animals immunized with antigenic preparations containing hsp, either in the form of whole mycobacteria or as purified recombinant hsp 65 , irrespective of any further antigens added and their normal serum cholesterol levels. These results suggest that an (auto)immune response to hsp65 may initiate the development of atherosclerosis (13).

It has been established that atherosclerotic lesions of humans and rabbits contain a large number of $T$ lymphocytes (14-18). Half of these T cells express MHC class II antigens, and some of them also IL-2 receptors (19), indicating a state of activation. Recent studies have shown that $\mathrm{T}$ lymphocytes in human atherosclerotic plaques are mostly memory cells expressing the low molecular weight form (CD45RO) of the leukocyte common antigen and the integrin very late activation antigen-1. These $T$ cells are polyclonal in origin based on the phenotype of $T$ cell antigen receptors, i.e., $\alpha / \beta$, or $\gamma / \delta(20$, 21 ). The presence of $T$ cells in atherosclerotic lesions could be important since these cells can secrete factors chemotactic for monocytes/macrophages and smooth muscle cells, as well as determine the differentiation and function of $B$ cells and monocytes/macrophages, and modulate lipoprotein uptake by the latter $(22,23)$.

To further scrutinize our concept that an immune reaction to hsp plays a role in the initial phase of the development of 
atherosclerosis, we used our previously established rabbit model to localize the hsp60 expression in the aortic intima and analyze the antigen specificity of $\mathrm{T}$ cells derived from atherosclerotic lesions from rabbits fed a cholesterol-rich diet or immunized with hsp65.

\section{Methods}

Animals, diets, reagents, and immunization. 38 New Zealand White male rabbits weighing between 1,800 and 2,200 $\mathrm{g}$ were obtained from Savo/Charles River Co. (Kisslegg im Allgäu, Germany). All animals were selected for serum cholesterol levels under $100 \mathrm{mg} / \mathrm{dl}$, individually housed in wire-bottomed cages at $22^{\circ} \mathrm{C}$ with a relative humidity of $55 \%$. All received water ad lib and were either fed a normal standard diet (T775; Tagger and Co., Graz, Austria) or a cholesterol-enriched $\operatorname{diet}(0.2 \% \mathrm{wt} / \mathrm{wt})$. The animals were separated into four groups and treated as shown in Table $I$.

FCA (lot no. 0638-60-7; containing $0.5 \mathrm{mg}$ Mycobacterium butyricum $/ \mathrm{ml}$ ), FIA and heat-killed Mycobacterium tuberculosis $\mathrm{H} 37 \mathrm{Ra}$ (lot no. 3114-33-8) were purchased from Difco Laboratories (Detroit, MI). Recombinant Mycobacterium bovis hsp65 was a gift from Dr. van Embden, National Institute of Public and Environmental Protection, Bilthoven, The Netherlands.

Immunization schedules for the various experimental groups are given in Table I. As indicated, rabbits received three intracutaneous injections into the back region. Each milliliter of emulsion consisted of $0.5 \mathrm{ml}$ protein solution or PBS, pH7.2, and $0.5 \mathrm{ml} \mathrm{FCA} \mathrm{or} \mathrm{FIA.}$

Blood cholesterol. Blood (1-2 ml) was taken from the central ear artery of rabbits fasted for $16 \mathrm{~h}$. The values of serum cholesterol were measured every 4 wk using an enzymatic procedure (Sigma Immunochemicals, St. Louis, MO). Briefly, $10 \mu \mathrm{l}$ serum was added to $1 \mathrm{ml}$ solution of cholesterol test kit and incubated for $18 \mathrm{~min}$ at room temperature followed by photometer measurement at $500 \mathrm{~nm}$ excitation wavelength (Dynatech Laboratories Inc., Alexandria, VA).

ELISA. Determination of hsp65 antibodies was assessed essentially as described (11). Briefly, recombinant hsp65 $(1 \mu \mathrm{g} / \mathrm{ml})$ was coated onto ELISA plate wells (Petra-Plastic, Würzburg, Germany) overnight at $4^{\circ} \mathrm{C}$. After washing with PBS ( $\mathrm{pH} 7.2$ ) supplemented with Tween 20 $(0.05 \%, \mathrm{vol} / \mathrm{vol})$, rabbit serum was added in appropriate dilutions and incubated for $1 \mathrm{~h}$ at room temperature. A swine anti-rabbit Ig horseradish peroxidase-labeled conjugate (lot no. P217; Dako, Copenhagen, Denmark) was then added and incubated for $1 \mathrm{~h}$ at room temperature after four washes with PBS/Tween. Finally $100 \mu$ l citrate phosphate buffer $(0.1 \mathrm{M}, \mathrm{pH} 4.2)$ containing $0.53 \mathrm{mg} / \mathrm{ml}$ of $2,2^{\prime}$-azino-bis 3-ethylbenzthiazoline-6-sulfonic acid (Sigma Immunochemicals) was added, and the absorbance was measured after $30 \mathrm{~min}$ at $490 \mathrm{~nm}$ with a Microelisa Autoreader (Dynatech Laboratories Inc.).

Atherosclerotic lesion measurement. Animals were killed by heart puncture under ketamine $(25 \mathrm{mg} / \mathrm{kg})$ and xylazine $(5-10 \mathrm{mg} / \mathrm{kg})$ anes- thesia. Serum was used immediately for tissue culture medium supplementation, and the rest stored frozen. The aortae were carefully removed intact from the aortic arch to the iliac bifurcation and cut longitudinally for macroscopic documentation of intimal lesions on a glass template. The size of the total surface area of the aortae covered by lesions were determined by computerized planimetry (IBM PC-AT 386 Image Analyzer, Programm "JAVA 1.4;" Jandel Scientific, Corte Madera, CA). These data were used to calculate the area (in square millimeters) of the intimal surface affected by atherosclerotic lesions. Several portions of uninvolved and lesioned aortic intima from each group were subdivided and further processed. For conventional histology, tissue fragments were fixed in $4 \%$ buffered ( $\mathrm{pH} 7.2$ ) formaldehyde, embedded in paraffin, and sectioned for hematoxylin-eosin staining.

Immunohistochemical staining. Serial $4-\mu \mathrm{m}$ thick frozen sections were cut from the cryopreserved tissue blocks, fixed in a cold 1:1 acetone-chloroform mixture for $10 \mathrm{~min}$, and washed with PBS for $20 \mathrm{~min}$. The sections were subsequently placed in a humidified chamber where they were overlayered with a monoclonal antibody ML-30 against mycobacterial hsp65 cross-reactive with mammalian hsp60 $(24,25)$ and incubated for $1 \mathrm{~h}$ at room temperature. After washing with PBS, sections were incubated with rabbit anti-mouse Ig (Dako) for $1 \mathrm{~h}$. Sections were washed in PBS three times, incubated with alkaline phosphatase-anti-alkaline phosphatase complex (Dako) for $30 \mathrm{~min}$, washed in PBS three times, and developed for $20 \mathrm{~min}$ at room temperature on a shaker using a substrate solution containing $9.8 \mathrm{ml}$ Tris buffer (0.1 M, pH 8.2), $0.2 \mathrm{ml}$ dimethylformamide, $8 \mathrm{mg}$ naphthol AS-MX phosphate, $3 \mathrm{mg}$ levamisole, and $10 \mathrm{mg}$ fast red TR salt (Sigma Immunochemicals).

Immunofluorescent double staining. Mouse monoclonal antibodies against rabbit $\mathrm{T}$ cells ( $\mathrm{L} 11$ / 135) and Ia antigens (2C4) (catalogue no. TIB1 88 and CRL 1760; American Type Culture Collection, Rockville, MD) derived from hybridoma supernatants or the ascites of BALB/c mice injected intraperitoneally with the respective hybridoma cells were purified and biotin labeled in our laboratory following established procedures (26). In short, ascites IgG was isolated by column chromatography on protein-G-Sephadex (Pharmacia, Uppsala, Sweden), labeled with biotin (Sigma Immunochemicals). Tetramethylrhodamine-isothiocyanate-labeled streptavidin for visualization of biotinylated antibodies was obtained from Jackson ImmunoResearch Laboratories, Inc. (West Grove, PA).

The procedure for immunofluorescence studies has been described previously (18). For visualization of nuclei, sections were counterstained with the DNA stain Hoechst $33258(1 \mu \mathrm{g} / \mathrm{ml}$ PBS; Lambda Probes, Graz, Austria) for $1 \mathrm{~min}$. Indirect immunofluorescence tests were performed on 4- $\mu \mathrm{m}$ frozen, acetone-fixed sections at room temperature. Finally, sections were mounted in gelvatol/PBS (1:10, vol/vol; Monsanto Chemical Co., Springfield, MA) and examined in an epiillumination immunofluorescence microscope equipped with appropriate filter combinations for the two wavelength method (Ortholux II; Leitz, Wetzlar, Germany).

Table I. Rabbit Experimental Schedule and Aortic Lesions

\begin{tabular}{clcccc}
\hline Group & \multicolumn{1}{c}{ Treatment } & Immunization & Diet & $\begin{array}{c}\text { Incidence/ } \\
\text { total of animals }\end{array}$ & Lesion area \\
\hline & & times & & & $m^{2} / a a_{1}$ \\
1 & Control & - & Normal chow & $1 / 9$ & $10.1 \pm 14.1$ \\
2 & 0.2 mg hsp65 & 3 & Normal chow & $9 / 10$ & $62.3 \pm 37.1^{*}$ \\
3 & Cholesterol & - & $+0.2 \%$ cholesterol & $13 / 13$ & $131.1 \pm 61.3^{*}$ \\
4 & FCA + cholesterol & 3 & $+0.2 \%$ cholesterol & $6 / 6$ & $287.9 \pm 143.6^{*}$ \\
\hline
\end{tabular}

In group 4, FCA was supplemented with mycobacteria tuberculosis $(1 \mathrm{mg} / \mathrm{rabbit})$. Immunization of rabbits was performed at a 5-wk interval. Cholesterol-rich diet was fed starting 2 wk after the beginning of the experiment. Animals were killed 16 wk after the first immunization except seven rabbits in group 3, which were used for culturing cells prepared from atherosclerotic lesions between 20 and 26 wk. All macroscopically detectable atherosclerotic lesions of the aortic intima were documented on a glass template and quantified by computerized planimetry. Values of the lesion area are given as mean \pm SD per aorta in each group except seven rabbits in group 3 . Statistical test was performed using the analysis of variance. * Significant difference from control, $P<0.05$. 
FACS analysis of blood mononuclear and spleen cells. $15 \mathrm{wk}$ after the first immunization, heparinized blood $(15 \mathrm{IU} / \mathrm{ml}$ preservative-free heparin; Immuno AG, Vienna, Austria ) was obtained from the central ear artery and diluted 1:2 in RPMI 1640 (Seromed, Berlin, Germany). Blood mononuclear cells were isolated by density gradient centrifugation over Lympho-Paque (density $1.086 / \mathrm{ml}$; Nyegaard and Co., Oslo, Norway) as described previously (27). After killing, rabbit spleens were removed and passed through a 120-mesh stainless steel net. The spleen cells were washed three times with RPMI 1640, incubated with $\mathrm{NH}_{4} \mathrm{Cl}$ buffer $\left(0.83 \mathrm{~g} \mathrm{NH}_{4} \mathrm{Cl}, 0.0037 \mathrm{~g} \mathrm{Na}\right.$-EDTA, $0.1 \mathrm{~g} \mathrm{KHCO}_{3} / 100$ $\mathrm{ml} \mathrm{H}_{2} \mathrm{O}$, pH 7.2) for $3 \mathrm{~min}$ to remove red blood cells, and washed with RPMI 1640.

For flow cytometric analysis cells $\left(1 \times 10^{6}\right)$ were incubated in PBS containing $1 \%$ BSA (Sigma Immunochemicals) in a total volume of $100 \mu \mathrm{l}$ with predetermined, appropriately diluted monoclonal antibodies $\mathrm{L} 11 / 135$ and $2 \mathrm{C} 4$ for $30 \mathrm{~min}$ at $37^{\circ} \mathrm{C}$. After three PBS- $1 \%$ BSA washes, the cells were incubated with FITC-conjugated Ig rabbit antimouse Ig for $1 \mathrm{~h}$ and washed again. Fluorescence measurements were performed in a fluorescence-activated cell sorter (FACScan ${ }^{\oplus}$, Becton Dickinson and Co., Mountain View, CA). Details of FACS settings and methods of quantification of fluorescence intensity for the labeled cells are described elsewhere $(27,28)$.

Splenocyte culture. Spleen cells $\left(1 \times 10^{6} /\right.$ well $)$ were cultivated in duplicate in round-bottomed microtiter plates (Nunc, Roskilde, Denmark ) in $0.2 \mathrm{ml}$ of RPMI 1640 supplemented with $1 \%$ fresh autologous serum, $5 \times 10^{-5} \mathrm{M} 2$-mercaptoethanol, streptomycin $(100 \mu \mathrm{g} / \mathrm{ml})$ and penicillin ( $100 \mathrm{IU} / \mathrm{ml}$ ), concanavalin A (Con A; Pharmacia) and antigens, including PPD (purified protein derivative of mycobacteria; Statens Seruminstitut, Copenhagen, Denmark) in concentrations indicated in Table II. The proliferative response of the cells was determined by measuring incorporation of $\left[{ }^{3} \mathrm{H}\right]$ thymidine $(1 \mu \mathrm{Ci} /$ well; sp act 5 $\mathrm{Ci} / \mathrm{mmol}, 185 \mathrm{GBq} / \mathrm{mmol}$; Amersham International, Amersham, United Kingdom) during the last $6 \mathrm{~h}$ of a $48 \mathrm{~h}$ culture at $37^{\circ} \mathrm{C}$ and $5 \%$ $\mathrm{CO}_{2}$. The stimulation index ( $\mathrm{SI}$ ) was calculated according to the following formula: $\mathrm{SI}=\mathrm{cpm}$ with antigen $\div \mathrm{cpm}$ without antigen.

$T$ cell cultures from atherosclerotic lesions. Under a hood and on ice, the atherosclerotic lesioned intima was sterilely dissected from the remaining media and adventitia with a scalpel and minced with scissors. Lesion cells were released from the minced intima by enzymatic digestion (1/10, wt/vol) according to Rosenfeld et al. (29). In brief, $1.0 \mathrm{~g}$ of minced intima was incubated with $10.0 \mathrm{ml}$ RPMI 1640 containing $450 \mathrm{U}$ collagenase (type VIIS), $5 \mathrm{U}$ elastase, and $1 \mathrm{mg} / \mathrm{ml}$ soybean trypsin inhibitor (all from Sigma Immunochemicals) for $1 \mathrm{~h}$ at $37^{\circ} \mathrm{C}$. The enzyme/tissue mixture was then filtered through a 100 $\mu \mathrm{m}$ nylon filter and fresh enzyme cocktail was added to the same minced tissue for an additional $1 \mathrm{~h}$. The released cells were then pelleted at $500 \mathrm{~g}$, and resuspended in RPMI 1640 . Viability was assessed by the ability of the cells to exclude trypan blue and averaged $>90 \%$.

Lesion cells were cultured either for proliferative response to antigens or for establishing $\mathrm{T}$ cell lines. For assessment of antigen responsiveness, cells $\left(1 \times 10^{6} /\right.$ well $)$ were cultured with supplements in the presence of autologous spleen feeder cells using the same procedures described above. For long-term cultures, lesion cells were propagated in
IL-2-containing medium obtained by supplementation with $25 \%$ conditioned medium, prepared by cultivating normal rabbit spleen cells with Con A in serum-free RPMI medium for $48 \mathrm{~h}$. The supernatant, termed conditioned medium, was harvested, concentrated, and absorbed with rabbit red blood cells to remove Con A (30). Feeder cells used in the present experiments were always autologous spleen cells stored frozen in liquid nitrogen and irradiated with 3,000 rads. Fresh medium containing $25 \%$ conditioned medium, $5 \%$ autologous serum, and feeder cells was added every 3 or $4 \mathrm{~d}$. Cell proliferation to antigens after a 2-wk culture was determined using the procedure described above.

Statistical tests in the present study were performed using analysis of variance and unpaired Student's $t$ test (Macintosh Computer; StatView SE + Graphics ${ }^{\mathrm{TM}}$ software), respectively.

\section{Results}

Serum cholesterol and antibodies to hsp65. Blood cholesterol levels remained below $100 \mathrm{mg} / \mathrm{dl}$ in rabbits immunized with hsp65, i.e., in the same range as untreated controls (Fig. 1). Thus, immunization alone does not elevate blood cholesterol levels in rabbits receiving a normal diet. On the other hand, rabbits of group 4 fed a cholesterol-enriched diet and simultaneously immunized three times with FCA showed higher blood cholesterol levels than rabbits receiving the cholesterol diet alone, although no statistical significance could be observed.

To assay serum antibody levels, ELISA plates were coated with recombinant mycobacterial hsp65, ovalbumin, or PPD. The data are summarized in Table II showing the expected significant increase of antibodies against hsp65 and PPD in immunized rabbits of groups 2 and 4, but no antibodies against the control antigen ovalbumin. Interestingly, OD values with sera from nonimmunized rabbits tested on hsp65-coated wells were significantly higher than ovalbumin coated wells. These findings are similar to our observations in healthy humans (11), and may reflect previous contact with bacterial hsp or reactivity against autologous hsp with high antigenic homology to bacterial hsp (31).

Phenotypic characterization of peripheral blood and spleen leukocytes. Previous studies revealed a certain effect of hypercholesterolemia on the leukocyte production in the bone marrow and/or on the circulation kinetics of leukocytes in the blood of rabbits (32). In the present experiments, the ratio of $\mathrm{T}$ lymphocytes and Ia-positive cells to the total number of blood mononuclear and spleen cells, respectively, was determined by FACS using monoclonal antibodies against rabbit $\mathrm{CD}_{3}$ and Ia antigens (Fig. 2). The number of $T$ cells in the blood and spleen showed no significant difference among the four groups, i.e., untreated control, hsp65 immunized, cholesterol diet, and FCA immunized plus a cholesterol-enriched diet. In contrast,

Table II. Antibody Specificity of Rabbit Sera

\begin{tabular}{lrlccc}
\hline Group & $n$ & \multicolumn{1}{c}{ Treatment } & Ovalbumin & PPD & Hsp65 \\
\hline & & \multicolumn{1}{c}{ In vivo } & $5 \mu \mathrm{g} / \mathrm{ml}$ & $3 \mu \mathrm{g} / \mathrm{ml}$ & $1 \mu \mathrm{g} / \mathrm{ml}$ \\
1 & 9 & Control & $26 \pm 31$ & $288 \pm 108$ & $268 \pm 154^{*}$ \\
2 & 10 & Hsp65 & $16 \pm 11$ & $23,385 \pm 16,662$ & $93,424 \pm 54,658^{*}$ \\
3 & 13 & Cholesterol & $21 \pm 10$ & $201 \pm 98$ & $224 \pm 136^{*}$ \\
4 & 6 & FCA + cholesterol & $37 \pm 23$ & $56,624 \pm 26,583$ & $11,024 \pm 8,194^{*}$ \\
\hline
\end{tabular}

Antibody titers of rabbit sera were determined with an ELISA using log dilution from 1:10 at $16 \mathrm{wk}$ after the first immunization. Cut off point for a positive titer: $\mathrm{OD}_{490}>0.10$. Values are means $\pm \mathrm{SD}$ of antibody titers. Statistical evaluation was performed using analysis of variance.

* Significant difference from ovalbumin, $P<0.05$. 


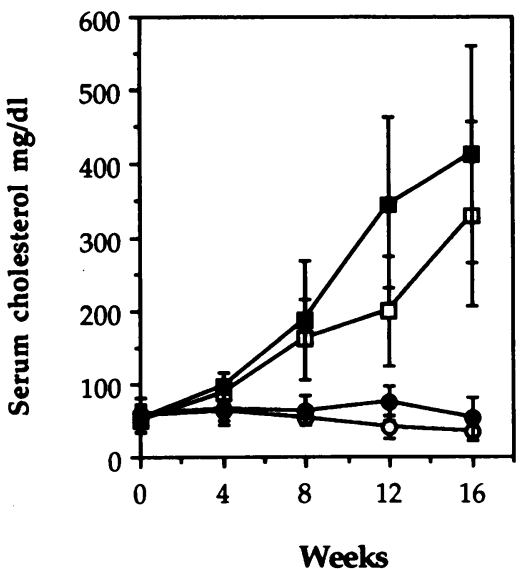

an increased number of $\mathrm{Ia}^{+}$cells was observed in the spleen and blood of hsp65 immunized animals (group 2) as well as those fed a cholesterol-rich diet alone (group 3 ) and those immunized plus cholesterol-rich diet (group 4). Generally, peripheral blood and spleen cells bearing Ia antigens are defined as monocytes/macrophages, B cells, spleen stromol cells, and activated $\mathrm{T}$ cells.

Macro- and microscopic assessment of atherosclerotic lesions. To confirm the previous notion of atherosclerosis induction by hsp 65 immunization, 10 normocholesterolemic rabbits were immunized with hsp65 from another source (a gift from Dr. van Embden, National Institute of Public and Environmental Protection). The results obtained in these experiments were similar to our previous observations (12). 9 of 10 rabbits showed arteriosclerotic lesions in the aortic arch and at the bifurcation of large arteries. Quantification of lesion-covered areas in the aortic intima revealed a significant increase in animals immunized with FCA and fed the cholesterol diet compared to those immunized with hsp65 or receiving a cholesterol
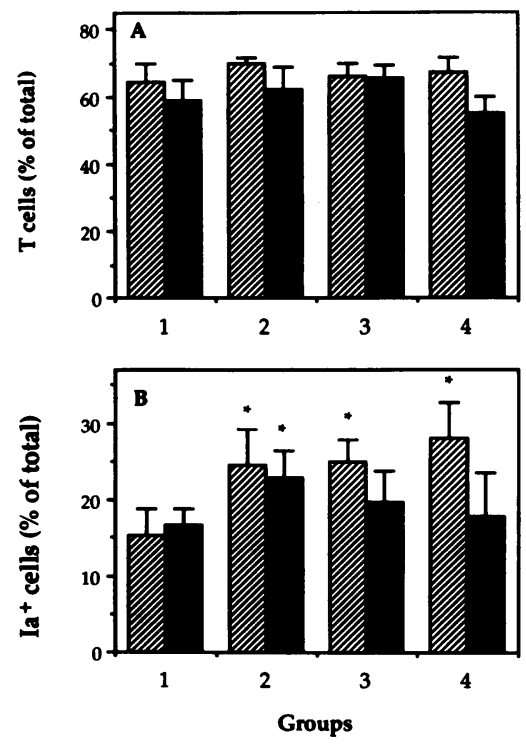

Figure 2. FACS analysis of blood mononuclear and spleen cells. Blood mononuclear cells $(\boldsymbol{\nabla})$ were isolated from heparinized peripheral blood by density gradient centrifugation over Lympho-Paque. Spleen leukocytes $(\mathbb{\mathbb { V }})$ were obtained by passing spleen tissue through a 120-mesh stainless steel net and removing red blood cells with $\mathrm{NH}_{4} \mathrm{Cl}$. The cells were labeled with monoclonal antibodies against rabbit pan $\mathrm{T}$ cells, $\mathrm{L} 11 / 135(A)$ and Ia antigen, $2 \mathrm{C} 4(B)$, respectively, and visual-

ized with a rabbit anti-mouse Ig-FITC conjugate. Fluorescence intensity of the labeled cells was determined by FACS analysis. Values are means $\pm \mathrm{SD}$ of positive cells from groups 1 to $4, n=5 /$ group. *Significant difference from control group $1, P<0.05$. diet alone (Table I). Histological characterization of lesions induced by immunization included intimal thickening and mononuclear cell infiltration without the occurrence of foam cells. In contrast, the combination of immunization with hsp65-containing material and cholesterol-rich diet provoked complicated atherosclerotic lesions consisting of mononuclear cell inflammation, foam cells, and necrotic debris similar to the classical human lesions (18).

Spleen cell response. Table III summarizes the results of proliferation assays of total spleen cells cultivated for $48 \mathrm{~h}$ in the presence and absence of various antigens, or the $T$ cell mitogen Con $\mathrm{A}$ as a positive control. It is obvious that spleen cells of all rabbits were strongly stimulated by Con A. As expected, the cells of immunized animals reacted specifically with hsp65 and PPD, an hsp65-containing material, but not with ovalbumin. Interestingly, spleen cells of untreated control and cholesterol diet rabbits also showed higher proliferative activity to hsp65 or PPD than spleen cells in medium without antigen, or with ovalbumin. These results are similar to the observations with serum antibodies and support the notion of prior contact with hsp-containing antigenic material, e.g., during infections.

Hsp65 staining in atherosclerotic lesions. From each group five aortic specimens were immunohistologically stained with monoclonal antibody ML-30 against mycobacterial hsp65. This antibody shows a cross-reaction with mammalian hsp60. Intimal endothelium, media, and adventitia of normal aortas showed very weak, if any, hsp65 staining. The lesion-covered areas of the intima from all rabbits, either hsp65 immunized, cholesterol-rich diet, or FCA-immunized plus cholesterol-rich diet, revealed an increased intensity of hsp65 immunostaining. The pattern of hsp65 staining in the lesioned aortas is shown in Fig. 3. Nonspecific reactivity was minimal in the corresponding negative controls (Fig. 3, $B, D$, and $F$ ). In the small-sized lesions, most areas within the intima had already become more intensely stained (Fig. $3 \mathrm{~A}$ ), whereas fatty streaks induced by the cholesterol-rich diet displayed elevated hsp65 content in the endothelial and subendothelial regions (Fig. $3 \mathrm{C}$ ). Heterogeneity of hsp65 staining became more evident in atherosclerotic plaques. Sites of increased hsp65 were mainly within the cap and base regions or in the surrounding necrotic debris of the atherosclerotic plaque (Fig. $3 E$ ). The hsp65 staining in the lesions appeared to be related more to cellular than extracellular components, as demonstrated on immunostained sections by counterstaining with Mayer's hemalaun.

Response of $T$ cells from atherosclerotic lesions. T cells constitute $10-20 \%$ of total cells revealed by nuclear counterstaining with a DNA dye in various stages of atherosclerotic lesions induced by cholesterol-rich diet (Fig. 4). More than half of the $\mathrm{T}$ cells were found to be $\mathrm{Ia}^{+}$in sections of atherosclerotic lesions and smears of dissociated lesion cells (Fig. 5). No significant difference of $\mathrm{Ia}^{+}$cells was found between the lesions in situ and cell isolates, excluding the possibility of a selective isolation of activated $\mathrm{T}$ cells. Over $90 \%$ of these dissociated cells were viable as assessed by trypan blue exclusion, thus providing the possibility for $T$ cell culture. Fig. 6 shows the results of proliferative assays with atherosclerotic lesion cells plus autologous feeder cells cultured for $48 \mathrm{~h}$ in the presence or absence of hsp65, with Con A as a positive control. Lesion cells of rabbits in experimental groups 2,3 , and 4 strongly responded to Con A stimulation. Interestingly, $\mathrm{T}$ cell proliferation to hsp65 was found not only in lesion cells from hsp65 immunized rabbits 
Table III. Antigen Specificity of Proliferative Response of Rabbit Spleen Cells

\begin{tabular}{|c|c|c|c|c|c|}
\hline \multirow[b]{2}{*}{ Group } & \multirow[b]{2}{*}{ Treatment } & \multicolumn{4}{|c|}{ Proliferative response $\left(\left[{ }^{3} \mathrm{H}\right]\right.$ thymidine uptake, $\left.\mathrm{SI}\right)$} \\
\hline & & Ovalbumin & PPD & Hsp65 & Con A \\
\hline & In vivo & $30 \mu \mathrm{g} / \mathrm{ml}$ & $30 \mu \mathrm{g} / \mathrm{ml}$ & $5 \mu \mathrm{g} / \mathrm{ml}$ & $l \mu g / m l$ \\
\hline 1 & Control & $1.01 \pm 0.56$ & $2.26 \pm 1.13$ & $2.64 \pm 1.16$ & $57.40 \pm 19.41$ \\
\hline 2 & Hsp65 & $0.95 \pm 0.67$ & $5.38 \pm 1.46^{*}$ & $4.73 \pm 0.56^{*}$ & $26.12 \pm 10.44$ \\
\hline 3 & Cholesterol & $1.15 \pm 0.66$ & $2.78 \pm 1.19$ & $1.78 \pm 1.11$ & $40.45 \pm 9.65$ \\
\hline 4 & Immunization + cholesterol & $1.00 \pm 0.49$ & $8.23 \pm 1.23^{*}$ & $3.93 \pm 2.01$ & $30.76 \pm 11.21$ \\
\hline
\end{tabular}

Spleen cells of rabbits killed 16 wk after the first immunization were harvested by passing a 120 -mesh steel net. The cells $\left(1 \times 10^{6} /\right.$ well $)$ were cultivated in duplicates in round-bottomed microtiter plates in $0.2 \mathrm{ml} \mathrm{RPMI} 1640$ medium containing $1 \%$ autologous serum and the indicated supplementations. The proliferative response of the cells was determined by measuring the incorporation of $\left[{ }^{3} \mathrm{H}\right]$ thymidine $(1 \mu \mathrm{Ci} /$ well $)$ that was added for the last $6 \mathrm{~h}$ of a 48-h culture. Values $\pm \mathrm{SD}$ (SI) are means of six rabbits from each group. Statistical test was performed using the analysis of variance. * Significant difference from control, $P<0.05$.

but also in those fed a cholesterol-rich diet exclusively. This T cell response to hsp65 in all three groups was significantly higher than that of cells cultured in medium only, suggesting the existence of $\mathrm{T}$ lymphocytes specifically reacting to hsp 65 in all types of atherosclerotic lesions of experimental animals.

T cell lines of atherosclerotic lesions. As described above, a large fraction of $T$ lymphocytes within atherosclerotic lesions was found to be $\mathrm{Ia}^{+}$, indicating activation. To assess the possibility of different reactions of activated T cells to hsp 65 of atherosclerotic lesion cells and blood leukocytes, blood mononuclear and lesion cells from the same rabbit were cultured and propagated in IL-2-containing medium for $2 \mathrm{wk}$. The $\mathrm{T}$ cell lines were cultivated with hsp65, ovalbumin, or Con $A$ in the presence of irradiated autologous splenocytes. The proliferative response of the cell lines to hsp65 established from the lesions was significantly higher than that from the autologous peripheral blood cells, although blood $\mathrm{T}$ cell lines also reacted stronger to hsp65 than ovalbumin (Table IV). Furthermore, the lesion $\mathrm{T}$ cell lines response to Con A was relatively poor compared to the blood derived cell lines.

\section{Discussion}

We have recently established an animal model of experimental atherosclerosis in normocholesterolemic rabbits by immunization with mycobacterial hsp65 (12). In the present experiments, increased expression of the mammalian homologous hsp60 in various types of atherosclerotic lesions induced either by hsp 65 immunization or a cholesterol-rich diet, was demonstrated by immunohistochemistry using a monoclonal antibody (ML-30) against mycobacterial hsp65. This murine monoclonal antibody has been found to react with a sequential epitope of M. tuberculosis hsp65 within residues 311-322 of which the tetrapeptide (315-318), shared with the mammalian hsp60 sequence, is a possible core for the antigenic determinant site (25). Recently, Hsp70 has been demonstrated in high levels in human atherosclerotic lesions (33). Evidence also indicates that surgical trauma entails a significant increase of hsp in the aorta compared to other organs, such as brain, lung, heart, liver, spleen, kidney, and skeletal muscle (9). This may be one of the reasons why atherosclerotic lesions usually localize in large arteries. Mechanisms leading to hsp65 expression in aortic endothelial cells may involve hemodynamic stress, while hypercholesterolemia itself may be an additional stress factor.
FACS analysis of peripheral blood and spleen leukocytes showed an increased number of MHC class II antigen-positive cells in those rabbits receiving a cholesterol-enriched diet, indicating a higher level of activated leukocytes. In hypercholesterolemic rabbits, aortic endothelial cells have been demonstrated to express mononuclear leukocyte adhesion molecule during atherogenesis (34). It is known that leukocytes adhere to endothelial cells in experimental animals as early as $1 \mathrm{wk}$ after initiation of cholesterol-rich diet (35-37). It remains to be clarified whether expression of hsp 60 and adhesion molecules in endothelial cells occur in parallel, and is followed by lymphocyte adhesion in these animal models.

$T$ cells in atherosclerotic lesions of rabbits constitute up to $20 \%$ of total lesion cells, most of which express MHC class II (Ia) antigens, i.e., are activated (12). To prove whether these T cells specifically respond to hsp65 participate in atherogenesis, we isolated and cultured $T$ cells from atherosclerotic lesions and compared them with PBL from the same animal. A population of $T$ cells in the lesions are hsp 60 antigen specific, supporting the hypothesis that $\mathrm{T}$ cells reacting to hsp 65 are involved in the development of atherosclerosis.

There are different mechanisms by which activated $T$ cells could emerge in the lesions. For example, there may be a preferential recruitment of $T$ cells that were already activated in the blood. This possibility is supported by the fact that a low number of activated $T$ cells specifically reacting against hsp 65 are always circulating in peripheral blood of rabbits (12) and humans (31), reflecting previous contact with this antigen. Such cells adhere to the endothelial cells to a much higher extent than resting $T$ cells (38). In addition, there is an increased expression of endothelial lymphocyte-adhesive molecules in atherosclerotic lesions (34), possibly resulting in preferential recruitment of activated $T$ cells. These cells could either maintain their activation state via local stimulation by hsp60 expressed in the lesions, or disappear and become replaced by other activated $\mathrm{T}$ cells recruited from the blood. Alternatively, $T$ cells may adhere to the endothelium and be recruited to the lesions in a nonactivated state, and receive their activating stimulation by hsp 60 already expressed on the surface of endothelial cells and in the intima.

The activated $\mathrm{CD}^{+} \mathrm{T}$ lymphocytes infiltrating in atherosclerotic lesions could recognize, and subsequently kill, the stressed cells to form necrotic debris in the core of the lesions. 

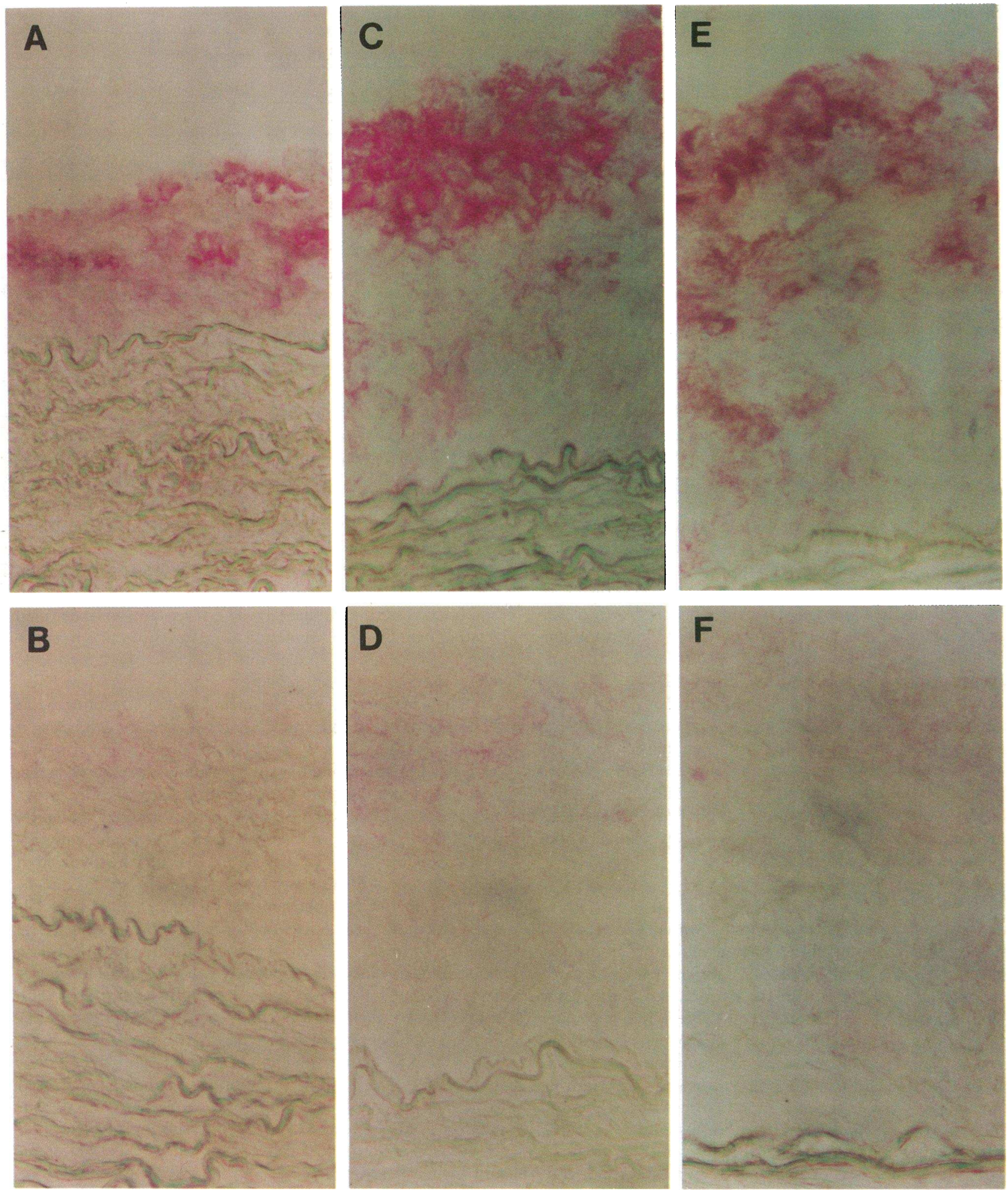

Figure 3. Detection of hsp65 in atherosclerotic lesions. Cryostat sections from the aortic arch of rabbits immunized with hsp65 on a normal diet for $16 \mathrm{wk}(A)$, from the descending aorta of a rabbit fed a $0.2 \%$ cholesterol diet for $14 \mathrm{wk}(C)$, and the thoracic aorta of an animal immunized with FCA and fed the cholesterol-rich diet for $14 \mathrm{wk}(E)$, were labeled with monoclonal antibody ML-30 against hsp65 and visualized with the alkaline phosphatase-anti-alkaline phosphatase system. Note the presence of positive staining in the intima of all types of atherosclerotic lesions. Sections $B, D$, and $F$ represent negative control aortas of the same rabbit corresponding to $A, C$, and $E$ treated with normal mouse IgG. Lumen of the aorta appears at the top of each photomicrograph, $\times 400$. 

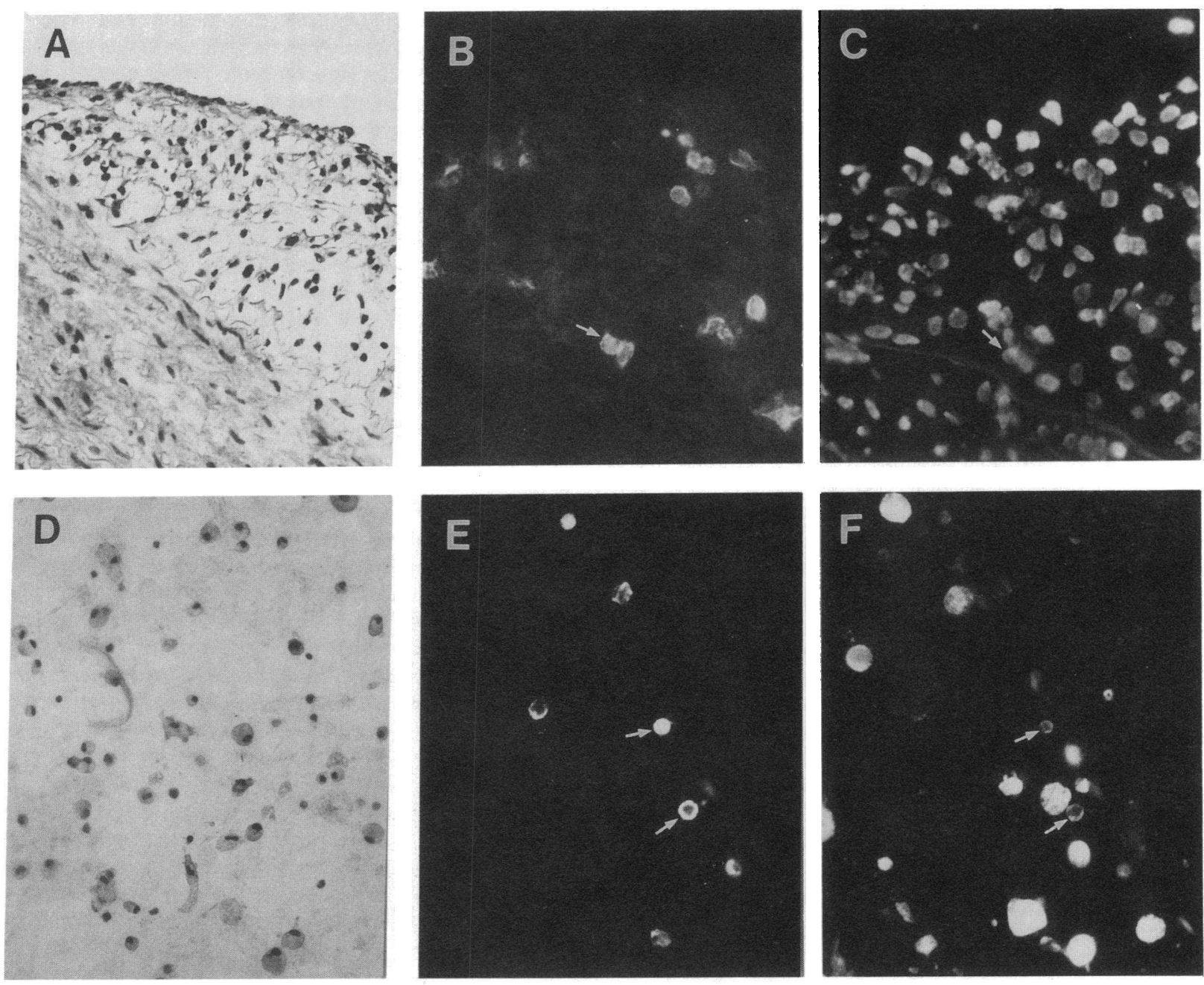

Figure 4. T lymphocytes in atherosclerotic lesions. Hematoxylin-eosin staining $(A ; \times 100)$, and double-immunofluorescence staining with a monoclonal antibody L11/135 and DNA dye (Hoechst 33258$)$ to simultaneously identify $\mathrm{T}$ cells $(B)$ and the cell nuclei $(C)$ in a lesion from the aortic arch of rabbits on the cholesterol-rich diet for $16 \mathrm{wk}$. Arrows denote identical cells, and the media of aorta appears at the bottom, $\times 250$. Hematoxylin-eosin staining $(D ; \times 200)$ and double-immunofluorescence staining of dissociated cells derived from atherosclerotic lesions from the aorta of rabbits on the cholesterol-rich diet for $20 \mathrm{wk}$ with the monoclonal antibodies $\mathrm{L} 11 / 135$ and $2 \mathrm{C} 4$ for T cells $(E)$ and Ia antigens $(F), \times 250$.

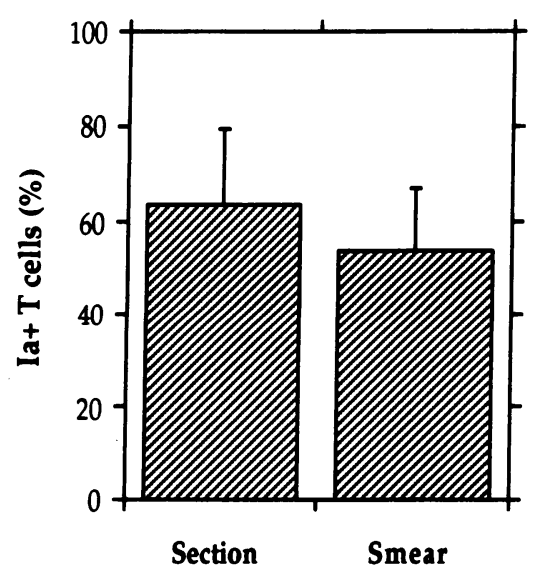

Single-positive cells and double-positive cells were enumerated at $\times 250$ in four visual fields. Values are means $\pm \mathrm{SD}$ of $\mathrm{Ia}^{+} \mathrm{T}$ cells percentage of total $T$ lymphocytes from five animals each group.
Figure 5. Frequency of $\mathrm{Ia}^{+} \mathrm{T}$ cells in atherosclerotic lesions and cell isolates. $\mathrm{Ia}^{+} \mathrm{T}$ cells were identified by double immunoflourescence staining with a monoclonal anti-pan $T$ cell antibody (L11/135) and a biotin-labeled monoclonal antibody against Ia (2C4) on cryostat sections and dissociated cell smears of atherosclerotic lesions induced by $0.2 \%$ sions induced by
When infiltrating $\mathrm{T}$ cells display the $\mathrm{CD} 4^{+}$phenotype they release several lymphokines that play an important role in the control of the biological behavior of vascular cells. For instance, endothelial and smooth muscle cells respond to gamma-interferon by expressing MHC class II antigens (18, 19), and thus, acquire the capacity to present foreign antigens to T cells in a "suicidal" fashion (39). Endothelial cells respond to TNF and gamma-interferon by expressing leukocyte adhesion molecules, e.g., vascular cell adhesion molecule-1, intercellular adhesion molecule-1, and endothelial leukocyte adhesion molecule (for review see references 40 and 41 ). Another lymphokine, macrophage colony-stimulating factor, was recently demonstrated to be elevated in atherosclerotic lesions of humans and rabbits $(42,43)$. Macrophage colony-stimulating factor can stimulate proliferation and immune activation of monocytes and mature macrophages, promote expression of the scavenger receptor and secretion of apo $E$ by macrophages (43), and enhance synthesis of inflammatory cytokines, such 


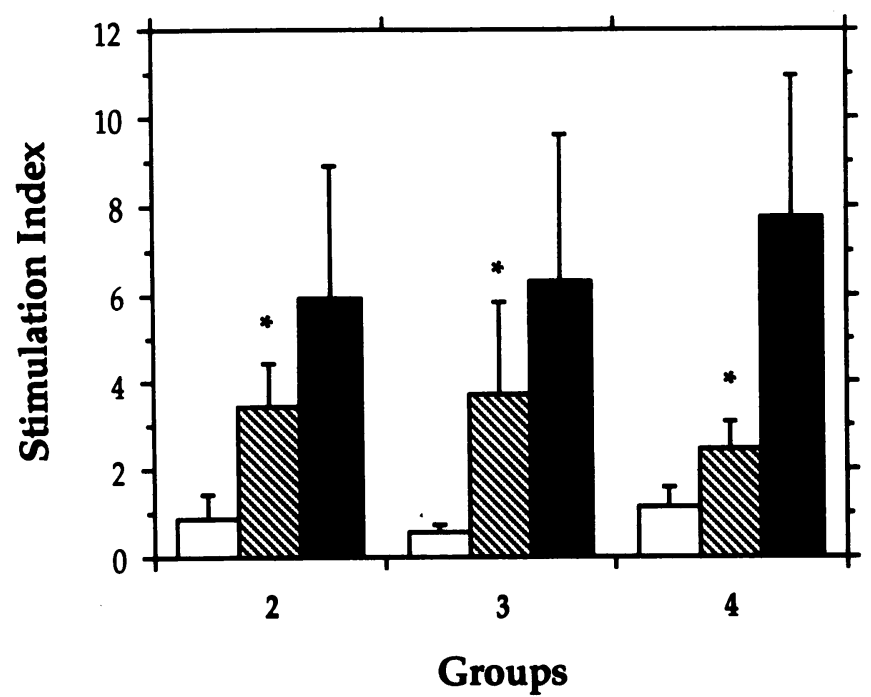

Figure 6. Hsp65 response of atherosclerotic lesion-derived T cells. Intimal areas covered by atherosclerotic lesions from rabbits immunized with hsp65 (group 2) on a normal diet for $16 \mathrm{wk}$, from rabbits fed a $0.2 \%$ cholesterol-rich diet (group 3 ) for $14 \mathrm{wk}$, or from animals immunized with FCA and fed the cholesterol diet (group 4) for 16 wk were removed from the aortic media, minced, and dissociated enzymatically. These cells $\left(1 \times 10^{6} /\right.$ well $)$ together with irradiated syngenic spleen cells $\left(5 \times 10^{5} /\right.$ well $)$ were cultured in duplicates in round-bottomed microtiter plates in $200 \mu \mathrm{l}$ of RPMI 1640 containing $1 \%$ fresh autologous serum supplemented with Con A ( 1 ), hsp65 ( $\mathbb{Q}$ ), or the medium only (control) for $48 \mathrm{~h}$ at $37^{\circ} \mathrm{C}$. Simultaneously, the irradiated spleen cells alone were stimulated with Con $\mathrm{A}$ as a further control ( $\square$ ). Cell proliferation was determined by measuring $\left[{ }^{3} \mathrm{H}\right]$ thymidine incorporation. Values are means $\pm \mathrm{SD}$ of stimulation index from five rabbits of each group. *Significant difference from the control, $P<0.05$.

as IL-1, and TNF by macrophages, which, in turn, become foam cells after lipid uptake, and accumulate in the subendothelium to form fatty streaks.

Interestingly, atherosclerosis shows several similarities to rheumatoid arthritis, which has been identified to be a hsp-related autoimmune disease (44). Patients with rheumatoid arthritis have significantly elevated serum antibody levels to mycobacterial hsp65 (44), and increased T cell reactivity to hsp65 in synovial fluid mononuclear cells compared to peripheral blood mononuclear cells $(44,45)$. The $T$ cell receptor pattern in rheumatoid synovium appears to be heterogeneous, suggesting a predominantly polyclonal origin of $T$ cells under these conditions. It is characterized by lesions with activated $T$ lymphocytes, HLA-DR-expressing synovial cells, and increased amount of hsp60 identified by immunohistochemical techniques with the same monoclonal antibody ML-30 used in the present experiments. Atherosclerosis is also an example for local, aberrant HLA-DR expression in tissues infiltrated by activated $T$ cells (14-18), which were identified as predominantly polyclonal (20). It is of interest that increased hsp60 expression coincides with accumulation of a fraction of $T$ cells reacting specifically with mycobacterial hsp65 in atherosclerotic lesions. As shown in the present study, this phenomenon, albeit to a different extent, was found in all types of lesions induced by hsp 65 immunization, cholesterol-rich diet, or FCA-immunization plus cholesterol-rich diet.
Furthermore, in healthy humans, circulating antibodies, and $\mathrm{T}$ cells reacting against mycobacterial hsp65, shared epitopes of mycobacterial and human $65(63)-\mathrm{kD}$ hsp have been found $(11,25,46)$. All animals used in our studies showed circulating antibodies and T cells reacting against hsp65 at significantly higher levels than against ovalbumin, as a nonrelevant antigen (12). Hsp show very high phylogenetic sequence homology not only between bacterial genera, but also throughout all higher forms of life $(1,2)$. The lifelong exposure to environmental microorganisms may partially explain the existence of a certain basic level of hsp-specific antibodies and $T$ cells in healthy subjects. It is also known that atherosclerotic lesions emerge in children as early as 10-12 yr of age (47). Blood cholesterol concentration alone is not a plausible explanation, since most of these children have normal or even relatively low blood cholesterol levels. Alternatively, various microbial infections in children can induce antibodies and $T$ cells specifically reacting against hsp65. A possible role of the specific antibodies and $\mathrm{T}$ cells in initiating stage of atherosclerosis in children should be taken into account in further studies.

Reactivity to the hsp65 antigen has been associated with adjuvant arthritis in rats (48), rheumatoid arthritis in humans (44), insulin-dependent diabetes mellitus in mice (49), and with atherosclerosis in humans (11) and rabbits (12). The hsp65 molecule features multiple lymphocyte epitopes and it is conceivable that among them there is one cross-reactive with an antigen in atherosclerotic lesions and another cross-reactive with an antigen present in joints. Indeed, the hsp65 epitope critical for adjuvant arthritis (amino acids 180-188) appears homologous to a sequence in the link protein of the cartilage proteoglycan (44). Hence, responses to different hsp65 epitopes might lead either to arthritis or to atherosclerosis. In therapeutic respects, vaccination with a nonapeptide, amino acid sequence $180-188$ of hsp65, was demonstrated to reduce incidence and severity of adjuvant arthritis in rats (50), and administration of hsp65 in PBS can vaccinate against diabetes in mice (49). In view of the possible role of hsp65/60 in the pathogene-

Table IV. Proliferative Responses of $T$ Cell Lines from Peripheral Blood and from Atherosclerotic Lesions Induced by Cholesterol-rich Diet

\begin{tabular}{lccc}
\hline \multirow{2}{*}{$\begin{array}{c}\text { Cell line } \\
\text { derived from }\end{array}$} & Hsp65 & Ovalbumin & Con A \\
\cline { 2 - 4 } & $5 \mu \mathrm{g} / \mathrm{ml}$ & $30 \mu \mathrm{g} / \mathrm{ml}$ & $2 \mu \mathrm{g} / \mathrm{ml}$ \\
& & & \\
Blood & $2.4 \pm 0.6$ & $1.1 \pm 0.4$ & $43.0 \pm 11.2^{*}$ \\
Lesions & $4.9 \pm 1.7^{*}$ & $1.8 \pm 0.5$ & $25.7 \pm 10.5$ \\
\hline
\end{tabular}

Lesion cells of rabbits which were fed with a $0.2 \%$ cholesterol-diet for 20-26 wk were isolated by dissociating aortic lesioned intima with enzyme solution. Blood mononuclear cells were isolated over Lympho-Paque. Both types of the cells were prepagated and maintained in RPMI medium supplied with $25 \%$ conditioned medium as an IL-2 source (vol/vol) and 5\% autologous serum for $2 \mathrm{wk}$. The cells (1-2 $\times 10^{4} /$ well) were cultured for $48 \mathrm{~h}$ in $150 \mu \mathrm{l}$ of the medium containing irradiated autologous splenocytes $\left(5 \times 10^{5} /\right.$ well $)$ with or without indicated antigens. Proliferative response of the cells was determined by measuring incorporation of $\left[{ }^{3} \mathrm{H}\right]$ thymidine. Values are means $\pm S D$ of SI (stimulation index) of five cell lines derived from peripheral blood and atherosclerotic lesions of five rabbits. * Significant difference, $P<0.05$. 
sis of atherosclerosis that has not been taken into account by others so far, caution should be exerted when recommending application of hsp for therapeutic or preventive purpose. On the other hand, if different hsp65 epitopes turn out to play a pathogentic role in different diseases, the use of different peptides will be indicated in these conditions.

Although the present experiments show that hsp65-evoked immune reactions play a certain role in the development of atherosclerosis in animal models, some questions remain to be answered. First, a large population of $\mathrm{T}$ lymphocytes in the lesions does not respond to hsp65. It is still not known whether these $T$ cells specifically react with other hsp, such as 70 present in human atherosclerotic lesions in high levels (33), and/or with other speculative antigens, including modified lipoproteins (51) that were recently demonstrated to induce $T$ cell activation in vitro (52) and to elicit autoantibodies in atherosclerotic patients (53), cryptic antigens released by necrotic cells (54), viruses (55), etc. Second, it is not clear that hypercholesterolemia is really a factor stressing endothelial cells to express hsp60 in higher levels in the initial stage of atherosclerosis in rabbits fed a cholesterol-rich diet. Finally, due to a limitation of specific reagents, e.g., lymphokines, antibodies, and cDNA probes for rabbits and the difficulty to maintain and propagate rabbit $T$ cells for more than 2 wk, further characterization of rabbit $T$ cell lines, including information if $T$ cells responding to mycobacterial antigens express the $\gamma / \delta \mathrm{T}$ cell receptor, is lacking at the moment. To answer several of the questions mentioned above further investigations are being carried out in our laboratory focusing on atherosclerotic lesions of humans and rats.

\section{Acknowledgments}

We thank Dr. J. D. A. van Embden, National Institute of Public Health and Environmental Protection, Bilthoven, The Netherlands, for kindly providing the recombinant mycobacterial hsp65 (M. bovis BCG 65K, batch no. mA-9A; the production of the hsp65 was supported by the UNDP/World Bank/WHO Special programme for research and training in tropical diseases); Dr. Juraj Ivanyi, Medical Research Council Tuberculosis and Related Infections Unit, Royal Postgraduate Medical School, Hammersmith Hospital, London, UK, for the monoclonal antibody ML-30 and critical reading of the manuscript; Dr. G. Böck for performing the FACS analyses, Dr. B. Grubeck-Loebenstein for discussions, A. Mair for excellent technical assistance, E. Rainer for help in animal experimentation, and I. Atzinger for the preparation of photographs.

Supported by a grant from the Austrian Research Council (project no. 8925), and the Austrian Ministery of Science and Research.

\section{References}

1. Young, R. A., and T. J. Elliott. 1989. Stress proteins, infection, and immune surveillance. Cell. 59:5-8.

2. Kaufmann, S. H. E. 1990. Heat shock proteins and the immune response. Immunol. Today. 11:129-136.

3. Subjeck, J. R., and T.-T. Shyy. 1986. Stress protein systems of mammalian cells. Am. J. Physiol. 250:C1-C17.

4. Donati, Y. R. A., D. O. Slosman, and B. S. Polla. 1990. Oxidative injury and heat shock response. Biochem. Pharmacol. 40:2571-2577.

5. Fincato, G., N. Polentarutti, A. Sica, A. Mantovani, and F. Colotta. 1991. Expression of a heat-inducible gene of the hsp70 family in human myelomonocytic cells: regulation by bacterial products and cytokines. Blood. 77:579-586.

6. Zimmerman, L. H., R. A. Levine, and H. W. Farber. 1991. Hypoxia induces a specific set of stress proteins in cultured endothelial cells. J. Clin. Invest. 87:908-914.

7. Knowlton, A. A., P. Brecher, and C. S. Apstein. 1991. Rapid expression of heat shock protein in the rabbit after brief cardiac ischemia. J. Clin. Invest. 87:139-147.
8. Delcayre, C., J. L. Samuel, F. Marotte, M. Best-Belpomme, J. J. Mercadier, and L. Rappaport. 1988. Synthesis of stress proteins in cardiac myocytes two to four days after imposition of hemodynamic overload. J. Clin. Invest. 82:460468.

9. Udelsman, R., M. J. Blake, and N. J. Holbrook. 1991. Molecular response to surgical stress: specific and simultaneous heat shock protein induction in the adrenal cortex, aorta and vena cava. Surgery (St. Louis). 110:1125-1131.

10. Garry, R. F., E. T. Ulug, and H. R. Bose, Jr. 1983. Stress protein induction occurs in eukaryotic cells following infection by diverse viruses in vitro. Virology. 129:319-332.

11. Xu, Q., J. Willeit, M. Marosi, R. Kleindienst, F. Oberhollenzer, S. Kiechl, T. Stulnig, G. Luef, and G. Wick. 1993. Association of serum antibodies to heat shock protein 65 with carotid atherosclerosis. Lancet. 341:255-259.

12. Xu, Q., H. Dietrich, H. J. Steiner, A. M. Gown, B. Schoel, G. Mikuz, S. H. E. Kaufmann, and G. Wick. 1992. Induction of arteriosclerosis in normocholesterolemic rabbits by immunization with heat shock protein 65 . Arteriosclerosis Thromb. 12:789-799.

13. Wick, G., R. Kleindienst, H. Dietrich, and Q. Xu. 1992. Is atherosclerosis an autoimmune disease? Trends Food Sci. Technol. 3:114-119.

14. Jonasson, L., J. Holm, O. Skalli, G. Bondjers, and G. K. Hansson. 1986. Regional accumulations of $\mathrm{T}$ cells, macrophages and smooth muscle cells in the human atherosclerotic plaque. Arteriosclerosis. 6:131-138.

15. Gown, A. M., T. Tsukada, and R. Ross. 1986. Human atherosclerosis. II. Immunocytochemical analysis of the cellular composition of human lesions. Am. J. Pathol. 125:191-207.

16. Munro, J. M., J. D. van der Walt, C. S. Munro, J. A. C. Chalmers, and E. L. Cox. 1987. An immunohistochemical analysis of human aortic fatty streaks. Hum. Pathol. 18:375-380.

17. Emeson, E. E., and A. L. Robertson, Jr. 1988. T lymphocytes in aortic and coronary intimas: their potential role in atherogenesis. Am. J. Pathol. 130:369376.

18. Xu, Q., G. Oberhuber, M. Gruschwitz, and G. Wick. 1990. Immunology of atherosclerosis: cellular composition and major histocompatibility complex class II antigen expression in aortic intima, fatty streaks, and atherosclerotic plaques in young and aged human specimens. Clin. Immunol. Immunopathol. 56:344-359.

19. Hansson, G. K., J. Holm, and L. Jonasson. 1989. Detection of activated T lymphocytes in the human atherosclerotic plaque. Am. J. Pathol. 135:169-175.

20. Stemme, S., J. Holm, and G. K. Hansson. 1992. T lymphocytes in human atherosclerotic plaques are memory cells expressing CD45RO and the integin VLA-1. Arteriosclerosis Thromb. 12:206-211.

21. Stemme, S., L. Rymo, and G. K. Hansson. 1991. Polyclonal origin of T lymphocytes in human atherosclerotic plaques. Lab. Invest. 65:654-660.

22. Miyajima, A., S. Miyatake, J. Schreurs, J. D. Vries, N. Arai, T. Yokota, and K. I. Arai. 1988. Coordinate regulation of immune and inflammatory responses by $\mathrm{T}$ cell derived lymphokines. FASEB (Fed. Am. Soc. Exp. Biol.) J. 2:2462-2471.

23. Fogelman, A. M., M. E. Haberland, and P. A. Edwards. 1984. Low density lipoprotein receptors and scavenger recetors on monocytes and macrophages: modulation by lymphokines. Lymphokines. 9:363-371.

24. Evans, D. J., P. Norton, and J. Ivanyi. 1990. Distribution in tissue sections of the human GroEL stress protein homologue. APMIS (Acta Pathol. Microbiol. Immunol. Scand.) 98:437-441.

25. Kiessling, R., A. Grönberg, J. Ivanyi, K. Söderstrom, M. Ferm, S. Kleinau, E. Nilsson, and L. Klareskog. 1991. Role of hsp60 during autoimmune and bacterial inflammation. Immunol. Rev. 12:91-111.

26. Heitzmann, H., and F. M. Richards. 1974. Use of the avidin-biotin complex for specific staining of biological membranes in electron microscopy. Proc. Natl. Acad. Sci. USA. 71:3537-3541.

27. Jürgens, G., Q. Xu, L. A. Huber, G. Böck, H. Howanietz, G. Wick, and K. N. Traill. 1989. Promotion of lymphocyte growth by high density lipoproteins. J. Biol. Chem. 264:8549-8556.

28. Traill, K. N., G. Böck, U. Winter, M. Hilchenbach, G. Jürgens, and G. Wick. 1986. Simple method for comparing large numbers of flow cytometry histograms exemplified by analysis of the CD4 antigen and LDL receptor on human peripheral blood lymphocytes. J. Histochem. Cytochem. 34:1217-1221.

29. Rosenfeld, M. E., J. C. Khoo, E. Miller, S. Parthasarathy, W. Palinski, and J. L. Witztum. 1991. Macrophage-derived foam cells freshly isolated from rabbit atherosclerotic lesions degrade modified lipoproteins, promote oxidation of low density lipoproteins, and contain oxidation-specific lipid-protein adducts. $J$. Clin. Invest. 87:90-99.

30. Krömer, K., K. Schauenstein, and G. Wick. 1984. Avian lymphokines: a Con A-erythrocyte complex induces higher T cell proliferation and IL-2 production than does free mitogen. J. Immunol. Methods. 73:273-281.

31. Munk, M. E., B. Schoel, and S. H. E. Kaufmann. 1988. T cell responses of normal individuals towards recombinant protein antigens of Mycobacterium tuberculosis. Eur. J. Immunol. 18:1835-1839.

32. Feldman, D. L., T. C. Mogelesky, B. F. Liptak, and R. G. Gerrity. 1991. Leukocytosis in rabbits with diet-induced atherosclerosis. Arteriosclerosis Thromb. 11:985-994. 
33. Berberian, P. A., W. Myers, M. Tytell, V. Challa, and M. G. Bond. 1990. Immunohistochemical localization of heat shock protein-70 in normal-appearing and atherosclerotic specimens of human arteries. Am. J. Pathol. 136:71-80.

34. Cybulsky, M. I., and M. A. Gimbrone, Jr. 1991. Endothelial expression of a mononuclear leukocyte adhesion molecule during atherogenesis. Science (Wash. DC). 251:788-791.

35. Gerrity, R. G., H. K. Naito, M. Richardson, and C. J. Schwartz. 1979. Dietary induced atherogenesis in swine: morphology of the intima in prelesion stages. Am. J. Pathol. 95:775-792.

36. Faggiotto, A., R. Ross, and L. Harker. 1984. Studies of hypercholesterolemia in the nonhuman primate. I. Changes that lead to fatty streak formation. Arteriosclerosis. 4:323-340.

37. Hansson, G. K., P. S. Seifert, G. Olsson, and G. Bondjers. 1991. Immunohistochemical detection of macrophages and $\mathrm{T}$ lymphocytes in atherosclerotic lesions of cholesterol-fed rabbits. Arteriosclerosis Thromb. 11:745-750.

38. Damle, N. E., and L. V. Doyle. 1990. Ability of human T lymphocytes to adhere to vascular endothelial cells and to augment endothelial permeability to macromolecules is linked to their state of post-thymic maturation. J. Immunol. 144:1233-1240.

39. Bottazzo, G. F., R. Pujol-Borrell, T. Hanafusa, and M. Feldmann. 1983. Role of aberrant HLA-DR expression and antigen presentation in induction of endocrine autoimmunity. Lancet. ii:1115-1118.

40. Butcher, E. 1991. Leukocyte-endothelial cell recognition: three (or more) steps to specificity and diversity. Cell. 67:1033-1036.

41. Berman, J. W., and T. M. Calderon. 1992. The role of endothelial cell adhesion molecules in the development of atherosclerosis. Cardiovasc. Pathol 1:17-28.

42. Rosenfeld, M. E., S. Ylaherttuala, B. A. Lipton, V. A. Ord, J. L. Witztum, and D. Steinberg. 1992. Macrophage colony-stimulating factor messenger RNA and protein in atherosclerotic lesions of rabbits and humans. Am. J. Pathol. 140:291-300.

43. Clinton, S. K., R. Underwood, L. Hayes, M. L. Sherman, D. W. Kufe, and P. Libby. 1992. Macrophage colony-stimulating factor gene expression in vascular cells and in experimental and human atherosclerosis. Am. J. Pathol. 140:301316.

44. Res, P. C. M., C. G. Schaar, F. C. Breedveld, W. van Eden, J. D. A. van Embden, I. R. Cohen, and R. R. P. de Vries RRP. 1988. Synovial fluid T cell reactivity against the $65 \mathrm{kD}$ heat-shock protein of mycobacteria in early onset of chronic arthritis. Lancet. ii:478-481.

45. Holoshitz, J., F. Konning, J. E. Coligan, J. D. Bruyn, and S. Strober. 1989. Isolation of $\mathrm{CD}^{-}$- $^{-\mathrm{CD}^{-}}$- mycobacteria-reactive $\mathrm{T}$ lymphocyte clones from rheumatoid arthritis synovial fluid. Nature (Lond.). 339:226-229.

46. Ivanyi, L., and J. Ivanyi. 1990 . Elevated antibody levels to mycobacterial 65-kDa stress protein in patients with superficial candidasis. J. Infect. Dis. 162:519-524.

47. Stary, H. C. 1989. Evolution and progression of atherosclerotic lesions in coronary arteries of children and young adults. Arteriosclerosis. (Suppl. I) 9:1932.

48. van Eden, W., J. E. R. Thole, R. van der Zee, A. Noordzij, J. D. A. van Embden, E. J. Hensen, and I. R. Cohen. 1988. Cloning of the mycobacterial epitope recognized by $\mathrm{T}$ lymphocytes in adjuvant arthritis. Nature (Lond.). 331:171-173.

49. Elias, D., D. Markovits, T. Reshef, R. van der Zee, and I. R. Cohen. 1990. Induction and therapy of autoimmune diabetes in the non-obese diabetic (NOD/ Lt) mouse by a 65-kDa heat shock protein. Proc. Natl. Acad. Sci. USA. 87:15761580.

50. Yang, X. D., J. Gasser, B. Riniker, and U. Feige. 1990. Treatment of adjuvant arthritis in rats: vaccination potential of a synthetic nonapeptide from the $65 \mathrm{kDa}$ heat shock protein of mycobacteria. J. Autoimmun. 3:11-23.

51. Steinberg, D., and J. L. Witztum. 1990. Lipoproteins and atherogenesis: current concepts. JAMA (J. Am. Med. Assoc.). 264:3047-3052.

52. Frostegård, J., R. Wu, R. Giscombe, G. Holm, A. K. Lefvert, and J. Nilsson. 1992. Induction of T-cell activation by oxidized low density lipoprotein. Arteriosclerosis Thromb. 12:461-467.

53. Salonen, J. T., S. Ylä-Herttuala, R. Yamamoto, S. Butler, H. Korpela, R. Salonen, K. Nyyssönen, W. Palinski, and J. L. Witztum. 1992. Autoantibody against oxidised LDL and progression of carotid atherosclerosis. Lancet. 339:883-887.

54. Libby, P., and G. K. Hansson. 1991. Involvement of the immune system in human atherogenesis: current knowledge and unanswered questions. $L a b$. Invest. 64:5-15.

55. Hajjar, D. P. 1991. Viral pathogenesis of atherosclerosis. Am. J.' Pathol. 139:1195-1211. 